\title{
Physico-chemical and heavy metals analysis of drinking water and their effect on human health: A Review
}

\author{
Abdul Basheer ${ }^{1,2}$, Attiq-ur-Rehman ${ }^{2}$, Samiullah ${ }^{2 *}$, Naqeebullah \\ $\mathrm{Khan}^{2}$, Hayatullah ${ }^{2,3}$ and Abdul Baqii ${ }^{2,3}$ \\ 1. Cadet College Pishin, Balochistan-Pakistan \\ 2. Department of Chemistry, University of Balochistan, Quetta 87300-Pakistan \\ 3. Colleges, Higher and Technical Education Department, Balochistan, Quetta 87300-Pakistan \\ *Corresponding author's email:sami435889@gmail.com \\ Citation \\ Abdul Basheer, Attiq-ur-Rehman, Samiullah, Naqeebullah Khan, Hayatullah and Abdul Baqi. Physico-chemical \\ and heavy metals analysis of drinking water and their effect on human health: A Review. Pure and Applied \\ Biology. Vol. 9, Issue 1, pp587-594. http://dx.doi.org/10.19045/bspab.2020.90064
}

\begin{tabular}{llll}
\hline \hline Received: 01/10/2019 & Revised: 03/12/2019 & Accepted: 11/12/2019 & Online First: 12/12/2019 \\
\hline \hline
\end{tabular}

\section{Abstract}

Water is the vital source for life and if it is contaminated by heavy metals can pose perilous repercussions on living beings. Therefore, this review is framed in which the concentrations of different heavy metals were quantitatively analyzed in different water bodies by different authors. The main elements under their observations were sodium, potassium, arsenic, cadmium, chromium, nickel, mercury, zinc, iron, magnesium, copper, manganese, cobalt and lead. Some studies revealed the detection of sodium and potassium through flame photometer while the concentrations of other aforementioned metals were detected by using Atomic Absorption Spectrometer (AAS). And their levels were compared with some of the most reputable environmental agencies of the world like WHO (2008), EUC (2001) and EPA (2007). The researchers also analyzed the physical parameters for water quantitatively like electrical conductivity, temperature, $\mathrm{pH}$, TDS, hardness, turbidity, alkalinity and salinity with the help of Digital Electronic Kits. Most of the water bodies present in the vicinity of industrial and municipal wastes were found highly polluted whereas the water bodies farther from these sources were aesthetically good in quality. In this study, the impacts of heavy elements on life have also been elaborated by quoting different research works.

Keywords: Human health; Heavy metals; Physico-chemical parameters; Pollution

\section{Introduction}

Sustaining of life without water is altogether impossible. Clean water is the key indicator for the development of any country. Naturally, water has most of the micronutrients with most balanced levels. But these levels have been highly disturbed by natural as well as to a greater extent by anthropogenic activities. Water related diseases are becoming the major problems in the world. In order to avoid any contamination of drinking water safe sources for the supply purpose are being used [1]. It has been reported that microbiological activities of water in vessels is lower than sources. Some researchers also suggest that contamination is widespread during storage and drawing of water supplies have a noteworthy activity to maintain the human stability on earth. Human being uses this supply as wellspring of irrigation, domestic water [2]. The increased rate of urbanization and industrialization has been threatened the 
quality of water available for living organisms [3].

Water Quality Index is a tool which tells the standard and level of drinking water [1]. Contaminated water causes hazardous effects to the health of the organism. Human health is at greater risk when confront in any form with heavy metals. They adversely affect the function of heart, brain, lungs and kidney while some of them such as mercury and arsenic are carcinogenic in nature. Groundwater which is one of the huge sources of fresh water contains most of the important minerals [4]. There are about 50 heavy metals among which 18 are highly toxic in nature. Vegetation is an important part of food chain can also be highly affected by heavy metals.

Arsenic (As)

Arsenic is the member of group VA in the periodic table with atomic number 33 , mass number 74.92 and density 5.72. Arsenic is the main constituent of most of the agrochemical. Sources of arsenic contaminations are fungicides, pesticides, sedimentary rocks, mining and metallurgy. It causes skin, lungs, kidney and bladder cancer, diabetes, reproductive toxicity and hearing loss [5]. Arsenic is found as organic complex e.g., dimethyl arsenic acid which is highly carcinogenic. According to WHO (2000), the acceptable limit of arsenic in drinking water is $0.01 \mathrm{mg} / \mathrm{L}$. Public Health Engineering Department of Pakistan (PHEDP) reviewed the concentration of arsenic with the collaboration of United Nations Children Emergency Fund (UNICEF) and conducted a survey of drinking water supply from wells in 2001. It was observed that Muzaffargarh District was one of the most arsenic polluted district (Table 1).

Table 1. Arsenic contamination in potable water

\begin{tabular}{|c|c|c|c|c|}
\hline Method & Permissible limit & Calibration range & Detection limit & Ref. \\
\hline $\begin{array}{c}\text { Anodic striping-linear } \\
\text { sweep voltammetry }\end{array}$ & $0.01 \mathrm{mg} / \mathrm{L}$ & $0.01-0.3 \mu \mathrm{M}$ & $10 \mathrm{nM}$ & {$[6]$} \\
\hline $\begin{array}{c}\text { Atomic absorption } \\
\text { spectroscopy }\end{array}$ & $0.01 \mathrm{ppm}$ & $0.001-0.0044 \mathrm{ppm}$ & $0.014 \mathrm{ppb}$ & {$[7]$} \\
\hline $\begin{array}{c}\text { Atomic absorption } \\
\text { spectroscopy, } \\
\text { Flame Emission }\end{array}$ & $0.01 \mathrm{ppm}(\mathrm{WHO})$ & $0.006-0.007 \mathrm{ppm}$ & $0.08 \mathrm{ppm}$ & {$[8]$} \\
\hline ICP-MS & -- & $0.021-0.092 \mathrm{ppm}$ & & {$[9]$} \\
\hline $\begin{array}{c}\text { Flame atomic absorption } \\
\text { spectroscopy }\end{array}$ & $0.01 \mathrm{ppm}$ & 0.00 & $0.08 \mathrm{ppm}$ & {$[10]$} \\
\hline
\end{tabular}

\section{Copper ( $\mathbf{C u})$}

Copper is the member of group IB in periodic table with atomic number 29 , mass number 63.54 and density 8.96. Copper has huge industrial applications in the modern world. It is also considered one of the most toxic elements which altogether change the water quality. Sources of contaminations are pesticides, mining, metal piping, paper industries. Thus, affecting health by increasing blood pressure, muscular cramp, skin irritation, stomach nausea, vomiting, anemia [3]. It is always present in our food and inside the animal liver. Copper acts as reductant in enzyme activities. The recommended dietary allowance (RDA) for children is $0.9 \mathrm{mg} / \mathrm{day}$. The concentration of coppers in different water samples were determined having range between $0.002 \mathrm{mg} / \mathrm{L}-0.075 \mathrm{mg} / \mathrm{L}$ [11]. High level of copper may lead to cause vomiting, abdominal pain, nausea, diarrhea and research have shown that copper leaches to drinking water from copper pipes [2] (Table 2). 
Table 2. Copper contamination in drinking water

\begin{tabular}{|c|c|c|c|c|}
\hline Methods & WHO limit & Calibration range & Detection limit & Ref. \\
\hline $\begin{array}{c}\text { Atomic absorption spectroscopy } \\
\text { (AAS) }\end{array}$ & $0.05 \mathrm{ppm}$ & $\begin{array}{c}0.002 \mathrm{ppm}-0.075 \\
\mathrm{ppm}\end{array}$ & $0.005 \mu \mathrm{g} / \mathrm{L}$ & {$[11]$} \\
\hline AAS, Flame Emission & -- & $0.04-0.06 \mathrm{ppm}$ & $0.007 \mu \mathrm{g} / \mathrm{L}$ & {$[8]$} \\
\hline ICP-MS & $0.05 \mathrm{ppm}$ & $0.031-0.192 \mathrm{ppm}$ & & {$[9]$} \\
\hline DPASV & $0.05 \mathrm{ppm}$ & $2-120 \mu \mathrm{g} / \mathrm{L}$ & $0.34 \mu \mathrm{g} / \mathrm{L}$ & {$[12]$} \\
\hline $\begin{array}{c}\text { Flame atomic absorption } \\
\text { spectroscopy }\end{array}$ & $0.05 \mathrm{ppm}$ & $0.01-0.21 \mathrm{ppm}$ & $0.001 \mu \mathrm{g} / \mathrm{L}$ & {$[10]$} \\
\hline
\end{tabular}

CL: confidence level

\section{Antimony (Sb)}

Antimony is member of group VA in periodic table with atomic number (51), atomic mass (121.5) and density (6.68). Antimony is found in the form of Antimony trioxide and potassium antimony tartrate. Antimony (V) is found in water which is not more harmful. It causes heart diseases and lungs impairment. The individuals are affected with this element by breathing defiled air, drinking sullied water or by eating sustenance's. Khan et al. (2017) have reported the concentration of antimony in drinking water from different areas of Quetta district, which ranged between $0.028 \mathrm{mg} / \mathrm{L}-0.03 \mathrm{mg} / \mathrm{L}$ (Table 3).

Table 3. Antimony contamination in water

\begin{tabular}{|c|c|c|c|c|}
\hline Method & Permissible limit & Calibration range & Detection limit & Ref. \\
\hline Voltammetry & $0.006 \mathrm{mg} / \mathrm{L}$ & Up to $0.3335 \mathrm{mg} / \mathrm{L}$ & $1.8 \times 10^{-4} \mathrm{mg} / \mathrm{L}$ & {$[13]$} \\
\hline $\begin{array}{c}\text { Atomic Absorption } \\
\text { Spectroscopy }\end{array}$ & $0.006 \mathrm{ppm}(\mathrm{EPA})$ & $\begin{array}{c}0.2774 \mathrm{ppm}-1.0214 \\
\mathrm{ppm}\end{array}$ & $0.0000008 \mathrm{mg} / \mathrm{L}$ & {$[7]$} \\
\hline AAS, Flame Emission & $0.006 \mathrm{ppm}(\mathrm{EPA})$ & $0.028-0.03 \mathrm{ppm}$ & $0.0000008 \mathrm{mg} / \mathrm{L}$ & {$[8]$} \\
\hline HPLC/ ICP-DRC-MS & 0.006 & Up to 0.045 & -- & {$[14]$} \\
\hline
\end{tabular}

\section{Lead (Pb)}

Lead is member of group IVA in periodic table with atomic number (82), atomic mass (207) and density (11.35). Lead is another highly toxic element which is found in earth crust in the form of galena $(\mathrm{PbS})$ widely used in paint, pesticides, smoking, automobile emissions, mining etc., and potential toxic effects are anemia, cancer, kidney failure, nervous system damage, mental retardation, vomiting, severe diarrhea [5]. EPA (Bangladesh, 2014) groups suggests that lead has high carcinogenic effects. Lead can cause many diseases like renal failure, coma and death. Lead originates from air, lead polluted soil or drinking water. Lead tainting is basic in more established water channels [10]. The work of different researchers may be summarized as below (Table 4).

Table 4. Lead contamination in water

\begin{tabular}{|c|c|c|c|c|}
\hline Method & WHO limit & Calibration range & LOD & Ref. \\
\hline Atomic absorption spectroscopy & $\begin{array}{c}0.015 \mathrm{ppm} \\
\text { WHO }\end{array}$ & $0.03 \mathrm{mg} / \mathrm{L}-0.06 \mathrm{mg} / \mathrm{L}$ & $0.01 \mathrm{mg} / \mathrm{L}$ & {$[7]$} \\
\hline AAS & $0.015 \mathrm{ppm}$ & $0.0097-0.00987 \mathrm{ppm}$ & $0.01 \mathrm{mg} / \mathrm{L}$ & {$[7]$} \\
\hline ICP-MS & ----- & $0.011-0.064 \mathrm{ppm}$ & $0.002 \mathrm{mg} / \mathrm{L}$ & {$[9]$} \\
\hline $\begin{array}{c}\text { Square wave anodic sweep } \\
\text { voltammetry (SWASV) }\end{array}$ & $0.015 \mathrm{ppm}$ & $1-20 \mu \mathrm{g} / \mathrm{L}$ & $\begin{array}{c}0.0001 \mathrm{mg} / \\
\mathrm{L}\end{array}$ & {$[6]$} \\
\hline AAS & --- & $0.08-0.24$ & $0.01 \mathrm{mg} / \mathrm{L}$ & {$[10]$} \\
\hline
\end{tabular}




\section{Cadmium (Cd)}

Cadmium is member of group IIB transition metals in periodic table with atomic number (48), atomic mass (112.4) and density (8.65). Sources of cadmium pollution are steel and plastic industries, electroplating, Nickle-cadmium batteries, welding etc. and its potential toxic effects are damage to kidney, cancer, bronchiolitis, fibrosis, skeletal damage [5]. Number of studies suggested that cadmium is a ubiquitous element which is mainly found in waste water. Its highest concentration was reported in Korangi industrial area of Karachi (5.35mg/L), which altogether exceeded by the WHO standard $(0.1 \mathrm{mg} / \mathrm{L})$. Moreover, north and east zones of Lahore district were also having more concentration of cadmium. DPASV (Differential pulse Anodic stripping voltammetry) analysis the concentration of cadmium was above the standard levels such as ranging from $0.01 \mathrm{ppm}$ to $0.11 \mathrm{ppm}$. The acceptable limit for $\mathrm{Cd}$ in drinking water is $0.005 \mathrm{ppm}$ [12]. Only 8 samples taken from potable water, showed no pollution of $\mathrm{Pb}$ and water samples had copper pollution all the other samples showed the pollution of lead $(\mathrm{Pb})$ and cadmium $(\mathrm{Cd})$. Author suggested that these water samples were not suitable for drinking [6]. Bajraktari et al. (2019) reported the concentration of cadmium in different water sample taken from river Drini I Bardhe. The concentration of cadmium was ranged between $0.002 \mathrm{mg} / \mathrm{L}$ - $0.005 \mathrm{mg} / \mathrm{L}$. An another report on the concentrations of some heavy metals in water of Mainefhi also Toker reservoirs present in Asmara city, Eritrea by utilizing flame photometric method [2]. They found cadmium in higher concentration in all samples $(0.0035 \mathrm{mg} / \mathrm{L})$ (Table 5).

Table 5. Cadmium contamination in water

\begin{tabular}{|c|c|c|c|c|}
\hline Method & WHO limit & Calibration range & LOD & Ref. \\
\hline AAS & $\begin{array}{c}0.005 \mathrm{ppm} \\
\text { (WHO) }\end{array}$ & $0.002 \mathrm{ppm}-0.005 \mathrm{ppm}$ & $0.003 \mathrm{mg} / \mathrm{L}$ & {$[11]$} \\
\hline $\begin{array}{c}\text { SWASV } \\
\text { (Square wave anodic } \\
\text { sweep voltammetry) }\end{array}$ & $0.005 \mathrm{ppm}$ & $0.00001-0.00015 \mathrm{mg} / \mathrm{L}$ & $7.4 \times 10^{2} \mathrm{mg} / \mathrm{L}$ & {$[6]$} \\
\hline AAS & $0.005 \mathrm{ppm}$ & $0.01-0.1 \mathrm{ppm}$ & $0.001 \mathrm{mg} / \mathrm{L}$ & {$[2]$} \\
\hline ICP-MS & -- & $0.001-0.0 .22 \mathrm{ppm}$ & $0.000008 \mathrm{mg} / \mathrm{L}$ & {$[9]$} \\
\hline
\end{tabular}

\section{Sodium (Na)}

Sodium is member of group IA with atomic number (11), atomic mass (23) and density (5.3). Sodium is an essential nutrient for human body which controls some of the important metabolic activities and transport system in plants and animals. It is found in water as $\mathrm{NaCl}$, and free ions. Yadav et al, (2012) reported that concentration of sodium was above the WHO limit in water samples of Agra city, India. Calibration range was between $126.5 \mathrm{ppm}-1254 \mathrm{ppm}$. Its permissible limit was $250 \mathrm{mg} / \mathrm{L}$ (Table 6).

\section{Potassium (K)}

Potassium is member of group IA with atomic number (19), atomic mass (39) and density (5.9). Potassium is found in water due to weathering of rocks, it has more concentration in polluted water [4]. It causes several diseases if increased from the permissible limit of WHO i.e. $50 \mathrm{mg} / \mathrm{L}$. Grachev et al. (2018) reported the concentration of potassium in water samples in Russia with value of $57 \mathrm{mg} / \mathrm{L}$. Yadav et al. (2012) reported the concentration of potassium in fresh water samples as varied between $1.9 \mathrm{mg} / \mathrm{L}$ $60.2 \mathrm{mg} / \mathrm{L}$ (Table 7). 
Table 6. Contamination of sodium in water

\begin{tabular}{|c|c|c|c|c|}
\hline Method & WHO & Calibration range & LOD & Ref. \\
\hline Flame AAS & $250 \mathrm{mg} / \mathrm{L}$ & $17.5 \mathrm{mg} / \mathrm{L}-37 \mathrm{mg} / \mathrm{L}$ & $0.1 \mathrm{mg} / \mathrm{L}$ & {$[10]$} \\
\hline $\begin{array}{c}\text { Wavelength-dispersive X-ray } \\
\text { fluorescence Spectroscopy } \\
\text { (WD-XRF) }\end{array}$ & $250 \mathrm{mg} / \mathrm{L}$ & $1000 \mathrm{mg} / \mathrm{L}-20000 \mathrm{mg} / \mathrm{L}$ & $74.1 \mathrm{mg} / \mathrm{L}$ & {$[5]$} \\
\hline $\begin{array}{c}\text { EDAX (Energy Dispersive X- } \\
\text { ray analysis }\end{array}$ & $250 \mathrm{ppm}$ & $5.83 \mathrm{mg} / \mathrm{L}-11.4 \mathrm{mg} / \mathrm{L}$ & & {$[15]$} \\
\hline $\begin{array}{c}\text { Analytic Hierarchy process } \\
\text { (AHP), } \\
\text { Fuzzy water quality index } \\
\text { (FWQI) }\end{array}$ & $250 \mathrm{mg} / \mathrm{L}$ & $2-5.7 \mathrm{mg} / \mathrm{L}$ & $0.1 \mathrm{mg} / \mathrm{L}$ & {$[16]$} \\
\hline $\begin{array}{c}\text { Gas chromatography- Mass } \\
\text { spectrometry (GC-MS) }\end{array}$ & $250 \mathrm{mg} / \mathrm{L}$ & $68.84 \mathrm{mg} / \mathrm{L}-68.94 \mathrm{mg} / \mathrm{L}$ & -- & {$[17]$} \\
\hline $\begin{array}{c}\text { Titration and Flame photometry } \\
\text { (model PFP7/C) }\end{array}$ & $250 \mathrm{mg} / \mathrm{L}$ & $190 \mathrm{mg} / \mathrm{L}-320 \mathrm{mg} / \mathrm{L}$ & ----- & {$[10]$} \\
\hline
\end{tabular}

Table 7. Contamination of potassium in water

\begin{tabular}{|c|c|c|c|c|}
\hline Method & WHO & Calibration range & LOD & Ref. \\
\hline $\begin{array}{c}\text { Wavelength dispersive X-ray } \\
\text { fluorescence Spectroscopy (WD-XRF) }\end{array}$ & $50 \mathrm{mg} / \mathrm{L}$ & $200 \mathrm{mg} / \mathrm{L}-1000 \mathrm{mg} / \mathrm{L}$ & $12.1 \mathrm{mg} / \mathrm{L}$ & {$[5]$} \\
\hline $\begin{array}{c}\text { Gas chromatography- Mass } \\
\text { spectrometry (GC-MS) }\end{array}$ & $50 \mathrm{mg} / \mathrm{L}$ & $11.48 \mathrm{mg} / \mathrm{L}-11.69 \mathrm{mg} / \mathrm{L}$ & ----- & {$[17]$} \\
\hline $\begin{array}{c}\text { EDAX (Energy Dispersive X-ray } \\
\text { analysis }\end{array}$ & $50 \mathrm{ppm}$ & $0.12 \mathrm{mg} / \mathrm{L}-1.8 \mathrm{mg} / \mathrm{L}$ & & {$[15]$} \\
\hline $\begin{array}{c}\text { Analytic Hierarchy process(AHP), } \\
\text { Fuzzy water quality index(FWQI) }\end{array}$ & $50 \mathrm{mg} / \mathrm{L}$ & $0.4 \mathrm{mg} / \mathrm{L} 2.6 \mathrm{mg} / \mathrm{L}$ & $0.2 \mathrm{mg} / \mathrm{L}$ & {$[16]$} \\
\hline $\begin{array}{c}\text { Spectroscopic methods } \\
\text { Titration and Flam photometry (model } \\
\text { PFP7/C) }\end{array}$ & $50 \mathrm{mg} / \mathrm{L}$ & $33-35 \mathrm{mg} / \mathrm{L}$ & $5 \mathrm{mg} / \mathrm{L}$ & {$[18]$} \\
\hline
\end{tabular}

\section{Iron $(\mathbf{F e})$}

Iron is member of group VIIIB in periodic table with atomic number (26), atomic mass (62) and density (7.67). Iron is an essential element for human health. It is the main component of protein, enzymes and hemoglobin. It acts as catalyst in metabolism and used for transport of gases in an out of the body. The tolerable upper intake level for adult is $45 \mathrm{mg}$ per day [12]. The concentration of iron was identified in water samples in Oban Massif, Nigeria with range from $0.07 \mathrm{mg} / \mathrm{L}-0.3 \mathrm{mg} / \mathrm{L}$ [3]. Various studies showed that the iron range was $0.01-11.3 \mathrm{ppm}$ in water; the highest value was reported from Kasur city, Pakistan [19]. All the results of concentrations of iron in water samples were compared with international reputed organization (WHO 2000) (Table 8).

\section{Physico-chemical parameters}

Physico properties were studied by Ugbaja \& Ephraim, (2019) which include EC, pH, COD, DO, TDS, TSS, Turbidity, alkalinity, etc. They reported the results having different ranges, temperature from $25.3^{\circ} \mathrm{C}-$ 26.6 ${ }^{\circ} \mathrm{C}, \mathrm{pH}$ from 4.35-6.20, EC from 16.6 $\mu \mathrm{s} / \mathrm{cm}-26.4 \mu \mathrm{s} / \mathrm{cm}$, TDS $(10.3 \mathrm{mg} / \mathrm{L}$ to $38.9 \mathrm{mg} / \mathrm{L})$, TSS $(0.02 \mathrm{mg} / \mathrm{L}$ to $1.5 \mathrm{mg} / \mathrm{L})$, DO $(3.09 \mathrm{mg} / \mathrm{L}$ to $9.88 \mathrm{mg} / \mathrm{L})$. Researchers have reported the Physico-chemical analysis of some water samples from Agra city, India [4]. They recommended and reported that the nature of drinking water of Agra city is not the point of confinement of WHO, and this city requires prudent 
measurements before utilizing water. Consequence of certain examples were as under (samples pH 7, TDS 1335mg/L, turbidity $6.5 \mathrm{NTU}, \mathrm{Ca}^{+2} 123 \mathrm{ppm}, \mathrm{Na}$ 313 ppm etc.). Researchers investigated and reported the bacteriological and Physicochemical parameters of surface and tap water quality in certain areas of Oban Massif, Nigeria [3]. They used Atomic absorption spectroscopic (AAS) techniques. They Checked and reported the
Physico-chemical properties of wet and dry sessions, the values were in satisfactory level of NSDWQ for wet session while if there should be an occurrence of dry session. TDS, turbidity, concentration of $\mathrm{Fe}, \mathrm{Mn}, \mathrm{NO}^{3-}$ and so forth were below as far as possible (temperature $25.4^{\circ} \mathrm{C}$ wet, $22 \mathrm{C} 0$ dry, $\mathrm{pH} 4.58$, wet $\mathrm{pH} 5.93$, Fe $0.07 \mathrm{ppm}$ wet, $0.115 \mathrm{ppm}$ dry, Mn $0.003 \mathrm{ppm}$ wet and $0.01 \mathrm{ppm}$ dry) (Table 9).

Table 8. Contamination of iron in water

\begin{tabular}{|c|c|c|c|c|}
\hline Method & WHO limit & Calibration range & LOD & Ref. \\
\hline $\begin{array}{c}\text { Flame atomic absorption } \\
\text { spectroscopy }\end{array}$ & $1.0 \mathrm{mg} / \mathrm{L}(\mathrm{WHO} 2011)$ & ND-0.64mg/L & $5 \mu \mathrm{g} / \mathrm{L}$ & {$[10]$} \\
\hline $\begin{array}{c}\text { ICP-MS \& Iron K-edge X-ray } \\
\text { absorption Spectroscopy }\end{array}$ & $0.3 \mathrm{mg} / \mathrm{L}$ & $1 \mathrm{mg} / \mathrm{L}-37 \mathrm{mg} / \mathrm{L}$ & $150 \mu \mathrm{g} / \mathrm{L}$ & {$[9]$} \\
\hline Spectroscopic methods & $0.3 \mathrm{mg} / \mathrm{L}$ & $0.01-0.050 \mathrm{mg} / \mathrm{L}$ & 0.001 & {$[20]$} \\
\hline $\begin{array}{c}\text { EDAX(Energy Dispersive X- } \\
\text { ray analysis }\end{array}$ & $0.3 \mathrm{ppm}$ & $0 \mathrm{ppm}-1.73 \mathrm{ppm}$ & & {$[15]$} \\
\hline
\end{tabular}

Table 9. Physical parameters with references

\begin{tabular}{|c|c|c|c|c|c|c|}
\hline $\begin{array}{l}\text { S. } \\
\text { No. }\end{array}$ & pH & $\begin{array}{c}\text { BOD (By } \\
\text { Respirometric } \\
\text { method) and by } \\
\text { Lovibond meter }\end{array}$ & $\begin{array}{c}\text { COD }(\text { By } \\
\text { Open reflux } \\
\text { method, Back } \\
\text { titration) }\end{array}$ & $\begin{array}{c}\text { TDS } \\
(\mathrm{mg} / \mathrm{L})\end{array}$ & EC & Ref. \\
\hline 1 & $7.71-8.39$ & & & $181-338$ & $412.2-8056.5$ & [11] \\
\hline & & $\begin{array}{l}80 \mathrm{mg} / \mathrm{L}- \\
500 \mathrm{mg} / \mathrm{L}\end{array}$ & $\begin{array}{l}118 \mathrm{mg} / \mathrm{L}- \\
957 \mathrm{mg} / \mathrm{L}\end{array}$ & & & [17] \\
\hline 2 & $4.58-6.31$ & & & $9.5-15.4$ & $16.6-23.5$ & [3] \\
\hline 3 & $7.2-7.7$ & & & $1020-3635$ & $1580-5200 \mu \mathrm{s} / \mathrm{cm}$ & [4] \\
\hline & & $\begin{array}{c}1.37 \mathrm{mg} / \mathrm{L}- \\
1.43 \mathrm{mg} / \mathrm{L}\end{array}$ & $\begin{array}{c}3.39 \mathrm{mg} / \mathrm{L}- \\
3.45 \mathrm{mg} / \mathrm{L}\end{array}$ & & & [17] \\
\hline 4 & $5.9-6.7$ & & & $240-450$ & $47-97$ & [10] \\
\hline
\end{tabular}

Water samples were collected from different areas tube wells located at district Pishin, province Balochistan, Pakistan by respective authors [7]. $\mathrm{As}, \mathrm{Pb}, \mathrm{Al}$ and $\mathrm{Sb}$ metals were analyzed by using Atomic spectrometry. Physical parameters like $\mathrm{pH}$, conductivity, colors, transparency etc. were also checked. Antimony and aluminum concentrations were $0.2774 \mathrm{ppm}$ $1.0214 \mathrm{ppm}$ and $0.7304 \mathrm{ppm}-1.7211 \mathrm{ppm}$ respectively. Authors suggested that as depth of the well increases as the amount of aluminum decreases. Local institutions should be gathered toward safe and quality water creations, as water is at risk of being contaminated. Water agencies should play a key role to establish awareness to clean the water of high quality. Tareen et al. [7] collected samples from Mardan district KPK Pakistan. They determined the concentration of following trace metals like $\mathrm{Ni}, \mathrm{Zn}, \mathrm{Cu}, \mathrm{Cd}, \mathrm{Cr}, \mathrm{Pb}$ and some cations like $\mathrm{Na}, \mathrm{Mg}, \mathrm{K}$ and $\mathrm{Ca}$. They concluded that the concentration levels of heavy metals were with in limit as said by WHO. Concentration ranges were as follow; $\mathrm{Ni}$ 
(0.01ppm-0.1ppm), $\quad \mathrm{Pb} \quad(0.00 \mathrm{ppm}-$ $0.03 \mathrm{ppm}), \quad \mathrm{Cr} \quad(0.01 \mathrm{ppm}-0.02 \mathrm{ppm}), \mathrm{Cd}$ (0.00ppm), Zn (0.01ppm-0.16ppm), $\mathrm{Cu}$ (0.00ppm-0.01ppm). Author suggested that the water samples result shows that water in Mardan district KPK Pakistan are suitable for drinking.

\section{Conclusion}

From the above review the authors concluded that samples which were examined were not suitable for drinking purposes, as they were having metals concentration more than permissible level allowed by (WHO, EPA, USEPA and EUC). Respective authors suggested that the drinking water needs constant care and monitoring as most of the human population is at significant risk. Higher content of heavy toxic metals cause kidney problem, digestive system problems, nervous disorders, etc. Potable drinking water should be filtered and cleaned before used by quality water agencies and modern desalination techniques. Most of diseases are associated with drinking water, if human use clean water and free from toxic metals, most of diseases will be controlled.

\section{Authors' contributions}

Conceived and designed the idea: AU Rehman, Samiullah, N Khan, Hayatullah \& A Baqi, Wrote the paper: A Basheer,

\section{References}

1. WHO, Guidelins for Drinking water Quality,World health organization $4^{\text {th }}$ edition 2011.

2. Tesfamariam Z, Younis HMY \& Elsanousi SS (2016). Assessment of heavy metal status of sediment and water in Maine fhi and toker drinking water reservoirs of Asmara city, Eritrea. Amer J Res Commu 4(6): 7688.

3. Ugbaja AN \& Ephraim BE (2019). Physio-chemical and bacteriological parameters of surface water quality in part of Oban, Massif, Nigeria. Glob J Geol Sci (17): 13-24.

4. Yadav KK, Gupta N, Kumar V, Arya S \& Singh D (2012). Physico-chemical analysis of selected ground water samples of Agra city, India. Rec Res Sci \& Tech 4(11): 51-54.

5. Jeong S, Kim YT \& Yoon HO (2019). Droplet method for the determination of sodium and potassium concentration in highly saline water samples using Xray Fluorescence spectroscopy. Spectr Acta part B Atom Spectr (153): 28-283.

6. Pandey SK, Singh P, Singh J, Sachan S, Srivastava S \& Singh SK (2016). Nanocarbon-based electrochemical detection of heavy metals. Electroanal 28(10): 2472-2488.

7. Tareen KA, Sultan NI, Parakulsuksatid, Shafi M, Khan A, Khan WM \& Hussain S (2014). Detection of heavy metals $(\mathrm{Pb}, \mathrm{Sb}, \mathrm{Al}$, As) through atomic absorption spectroscopy from drinking water of District Pishin, Baluchistan, Pakistan. Inter J Cur Micro Appl Sci 3(1): 299308.

8. Khan M W, Khalid M, HabibUllah HUR, Ayaz Y, Ullah F, Jadoon MA \& Afridi S (2017). Detection of Arsenic (As), Antimony (Sb) and Bacterial Contamination in Drinking Water. In Bio, Form (9): 133-238.

9. Islam MS, Ahmed MK, Raknuzzaman M \& Habibullah-Al-Mamun (2015). Heavy metal pollution in some surface water and sediment: A preliminary assessment of an urban river in a developing country. Eco Indi (48): 282-291.

10. Jamil A, Khan T, Majeed F \& Zahid D (2019) .Drinking water quality Characterization and heavy metal analysis in spring of Dewan Gorah, district palandri, Azad Jammu and Kashmir, Pakistan. Inter $J$ Econ Environ Geol 9(3): 33-39.

11. Bajraktari N, Kastrati G, Morina I \& Bajraktari Y (2019). Exploration of physico-chemical parameters in environmental matrices of the river Cerica and a segment of the river Drini I Bardhë. J Eco Eng 20(4): 127-135.

12. Mora K de, Joshi N, Balint BL, Ward BF, Elfick A \& French CE (2011). A 
$\mathrm{pH}$-Based biosensor for detection of arsenic in drinking water of south East Hungary. Anal Bioanal Chem (400): 1031-1039.

13. Chomistekova LZ \& Tomcik P (2018). Voltammetric detection of antimony in natural water on cathodically pretreated microcrystalline boron doped diamond electrod: A possibility how to eliminate interference of arsenic without surface modification. Talanta 178: 943-948.

14. Marcinkowska M, Komorowicz I \& Baratkiewicz D (2016). New procedure for multielemental speciation analysis of five toxic species: As(III), As (V), Cr (VI), Sb (III) and $\mathrm{Sb}(\mathrm{V})$ in drinking water samples by advanced hyphenated technique HPLC/ICP-MS. Anal Chim Acta 920: 102-111.

15. Naveen BP, Mahapatra DM, Sitharam TG \& Sivapullaiah PV (2016). Physico-Chemical and biological characterization of urban municipal Landfill leachate. Environ Pollu 220 : $1-12$.

16. Abdullah M, Mamun A and Azad MS (2019). Assessment of surface water quality using Fuzzy Analytic Hierarchy Process(FAHP): A case study of Piyain river;s sand and gravel quarry mining area in Jaflong, Sylhet. Grnd Water Sust Develop 9: 100208.

17. Kurnaz A, Mutlu E \& Uncumusaoglu AA (2016). Determination of water Quality parameters and heavy metal content in surface water of Cigdem pond (Kastamonu/Turkey). Turk J Agri Food Sci Tech 4(100): 907-913.

18. Mekapogu M, Nadimikeri J, Madri PK \& Devi S (2017). Astudy on zinc speciation of Tungabhra river sediments,Kurnool,South India; A tool on metal pollution monitoring. inter $J$ Sidmt Resea 33(4): 510-517.

19. Khan s, Shah IA, Muhammad S, Malik RN, \& Shah MT (2015). Arsenic and heavy metal concentration in drinking water in Pakistan and risk assessment: a case study. Hum Ecol Risk Asst 21: 1020-1031.

20. Ancic M, Huđek AI \& Rihtarić MC (2019). Physico-chemical properties and toxicological effect of landfill ground water and leachates .Chemospr 238: 124574. 